

\section{Determinants of Foreign Direct Investment: A Panel Data Analysis for Sub-Saharan African Countries}

\section{Semra Boğa}

\section{Introduction}

One of the major economic issues of developing countries is the shortage of domestic resources necessary to subsidize national investments. This leaves countries in constant need for both indirect and direct investments. Initially, developing countries, which have been on the path to lending from predominantly international banks, have started to redesign their foreign investment policies and business climate to attract more stable foreign capital types, since the debt crises in the 1980s restricted access to credit. Due to its structure, direct investments, which give ownership rights to the investor and require a certain physical investment, have been considered the most secure and largest component of capital flows in developing countries by being seen as a good alternative to foreign capital flows coming in the form of bank loans.

Along with the globalization trends seen in the post-1990 period, there has been a significant change also in the attitude towards foreign direct investment (FDI) in developing countries. The debate among academics and policy-makers on whether to encourage FDI or not has largely been replaced by how FDI should be encouraged. The fact that the World Bank and some other international development agencies have proposed FDI as one of the most effective tools in fighting against the global poverty by increasing employment, technological know-how and competitiveness has motivated less developed and developing countries to pursue policies to encourage FDI inflows.

FDI is also seen as an important source of poverty alleviation for African countries with inadequate financial resources, technological and production infrastructure. United Nations Economic Commission for Africa (UNECA) claims that, foreign investment is the main factor in coping with the financial issues of Africa in their African Economic Report. Institutions like the IMF and the World Bank have asserted that, big inflows of FDI would lead to economic development and that sub-Saharan African governments are very keen to attract FDI. Indeed, most African countries have taken significant measures to attract FDI. First, countries in the region have implemented FDI-specific legislative frameworks to promote their investment goals.

These measures included the establishment of investment incentive agencies and facilities and the creation of specific plans to attract investments such as Export Processing Zones (EPZs) and Special Economic
Zones (SEZs). By 2019, total number of SEZs reached to 237 established by 32 countries (UNCTAD, 2019). In addition, initiatives have been taken at the global level by signing the Bilateral Investment Treaties (BITs) and Double Taxation Treaties (DTTs). The number of BITs signed in Africa reached to almost 1000 and DTTs went over 500 in 2012 (UNECA, 2016).

However, despite all the efforts and new regulations implemented, FDI inflows have not reached to desired levels in Sub-Saharan African countries. FDI inflows to developing countries showed a substantial increase since the beginning of the $21^{\text {th }}$ century, reaching $\$ 706$ billion (54\% of total investment) in 2018, which was \$ 24 billion in 1990 (24\% of total investments) (UNCTAD, 2019). This has been a good development, especially for poor and underdeveloped countries with no access to international capital markets. Africa, however, the poorest region in the world, has not benefited from this increase in FDI inflows. For example, in 1980-1989 and 1990-1998, investments in Sub-Saharan Africa increased by only $59 \%$. Considering that FDI inflows to developing countries increased by $672 \%$ in the same period, the increase in Sub-Saharan Africa is quite low (Asiedu, 2002). Due to the unstable structure of foreign aid and the volatility of portfolio flows, attracting various types of FDI in the region is essential.

Given that FDI will accelerate growth and development by enhancing employment, managerial skills and technology, it is worrying that the region, which does not have the financial resources required for investments, cannot attract enough foreign investment. FDI is critical in this region, where domestic savings and incomes are quite low, due to the generally high levels of poverty, to catch the other developing countries' economic growth and development.

As mentioned in the United Nations Millennium Declaration, a significant improvement in FDI levels would help the region halve the Millennium Development Goal (Millennium Development Goals) in 2015 to reduce poverty rates. Based on Africa's Development (NEPAD) statement, the region must fill an annual resource gap of $\$ 64$ billion, for the continent to meet the Millennium Development Goals. Due to low income levels and domestic savings in the region, most of the finance will have to come from abroad. However, official assistance to the region is diminishing. Moreover, most of the countries in Africa have no access to global financial funds which leaves the FDI as the best alternative resource to overcome the poverty in the region. The annual FDI flow was an average of $\$ 7$ billion between 1995 and 2001. Therefore, filling the annual resource gap of $\$ 64$ billion needed for poverty reduction will require a significant increase in FDI (Asiedu, 2006)

The Sub-Saharan Africa area, which is the subject of this study, is made up of 48 countries, most of them in the list of least developed nations with trouble attracting foreign investment due to investors' perception of the risky region because of the bad business environment. Even though the region has a rich variety of natural resources and a big population; corruption, very low level of employment, political conflicts and poor infrastructure impede these countries to fully realize their potential. Both academic studies and UNCTAD reports have shown that in order to attain sustainable growth and 
decrease poverty, national and foreign investments must be encouraged in the region.

After two consecutive years of decline, FDI inflows to Sub-Saharan Africa increased by $13 \%$ in 2018 and rose to $\$ 32$ billion. The main reasons behind this increase in FDI were the recovery in the resource-seeking investment, and the increase in investments in South Africa, the continent's second largest economy. These two developments compensated the significant declines in FDI to some countries in the sub-region due to political uncertainty and unfavorable economic fundamentals. Moreover, increasing demand and rising prices for some commodities also contributed to the increase in investments. However, lower than forecasted global economic growth, accelerating trade tensions and moderate growth in Sub-Saharan Africa were the factors limiting the magnitude of FDI growth. In 2019, the anticipated increase in Africa's financial development, progress towards the application of the African Continent Free Trade Area Agreement and some big greenfield investments are regarded factors that will stimulate the foreign investments in the area (UNCTAD, 2019).

Considering the latest improvements in FDI flows to Sub-Saharan African region, it is worthwhile to investigate the factors that drive the foreign investment. There exists numerous empirical studies estimating the determinants of FDI inflows in developed and developing countries. However, the absence of the generally agreed determinants of FDI inflows both in terms of theoretical and empirical findings motivates the researchers to scrutinize this topic. Studies on SubSaharan African countries have mostly focused on natural resources in these countries as the main determinant of FDI inflows. In some other studies conducted for developing countries determinants such as economic growth, trade openness, financial development, infrustructure and macroeconomic stability have been found as important determinants of FDI inflows in accordance with the theoretical literature in this field. Therefore, this study aims to close the gap in the literature by testing these variables for Sub-Saharan African countries. The findings of the study are believed to shed a light on the policies of African countries to attract more foreign investment.

The paper is structured with five sections. In the following section, the theoretical and conceptual framework of FDI determinants will be explained. In section III, the findings of the empirical literature will be analyzed. In section IV, steps of the econometric analysis will be presented. Finally, in the conclusion part, empirical findings of the study will be elaborated.

\section{The Determinants of FDI: Theoretical and Conceptual Framework}

In the economics literature, FDI is defined as a type of investment made by a foreign investor by acquiring a company, providing an establishment capital for a new firm or increasing the capital of an existing firm in the host country, bringing technology, management knowledge and control of the investor on the invested country (Karluk, 2009). One of the first attempts to explain the FDI was made by classical economist David Ricardo in his theory of comparative advantages. However, assumptions of this theory, such as two country, two products and the full mobility of production factors were insufficient to explain the globally rising FDI trends (Denisia, 2010). Theories developed in the field of FDI mainly seek answers to questions such as why a company established in the home country invests in another country, how it can compete with local firms in the foreign country of investment, and why companies prefer to invest directly instead of export or license agreements.

According to Vernon (1966), an innovative product first emerges in the United States or in other developed countries, where technology and skilled workforce are advanced. In his theory of "Product Life Cycle", he argues that in the first stage of the cycle, only the products sold in the domestic market are exported to foreign countries due to increased production. After the export stage, the producers choose to directly invest to produce and sell the products in other countries. On the other hand, in his theory called "Oligopolistic Reaction" Knickerbocker (1973), suggested that investors take the decision of FDI to follow the behavior of their competitors who invested in another country to move from exporting stage to direct investment. In his "Industrial Organization Theory", Hymer (1976) argues that companies that are currently exporting products will invest directly in the host countries in order to compete with local producers in these countries. However, in order to make international investments profitable, companies need to have superior advantages such as know-how, scale economie, access to cheap financial resources, marketing and management skills. According to "Internalization Theory" developed by Buckley and Casson (1976), market disruptions in the host country can be prevented by FDI in the country. Companies use vertical and horizontal integration techniques and with direct investments in different countries, a product manufactured by one of the subsidiaries can be used as an input in another subsidiary.

The "Eclectic" or "OLI Paradigm", developed by Dunning in the late 1970s, has been the most recognized and cited work than other models in terms of explaining the FDIs in a more holistic approach compared to aforementioned theories based on market disruptions. Of the initials constituting the model "O" represents ownership advantages, " $L$ " represents location specific advantages, and "I" represents internalization advantages. According to Dunning, FDI should only be made if these advantages are realized at the same time. Ownership advantages include leading-edge technologies, specialized manufacturing processes, patents, and managerial skills. Locational advantages such as special tax regimes, low production and transportation costs, market size, access to protected markets and low risk are considered important factors for the profitability of the investment. Finally, risks arising from market failures can be mitigated by using internalization advantages (Pedersen, 2003).

Looking at the underlying motivation behind the investment, Dunning (1993) proposes three different types of FDI: Market-seeking, resource-seeking, and efficiency-seeking. According to Dunning, the factors that investors take into consideration when choosing a country to invest will vary according to these three types of investment. For example, a market-seeking (also called horizontal) FDI whose aim is to provide easy access to local and regional markets will focus on factors such as market size and economic growth potential of the 
host country. Investors will consider investing directly, especially in situations where it is difficult to enter the country via export due to high tariffs or transportation costs. The main motivation of the resource-seeking FDI is to provide access to natural resources (natural gas, oil, minerals etc.), raw materials or low-cost labor in the host country. Especially for the multinational companies considering to invest in the manufacturing sector for export purposes, the factor endwoments in the host country will be an important attraction factor. Finally, the efficiency-seeking FDI aims to benefit from the common management by combining the geographically dispersed activities of the company in one country in the presence of economies of scale and scope.

UNCTAD, making use of also the findings of Dunning, has established a report in 1998 defining the host county determinants of FDI. Below figure shows the political, economic and business environment related determinants of FDI in the host country.

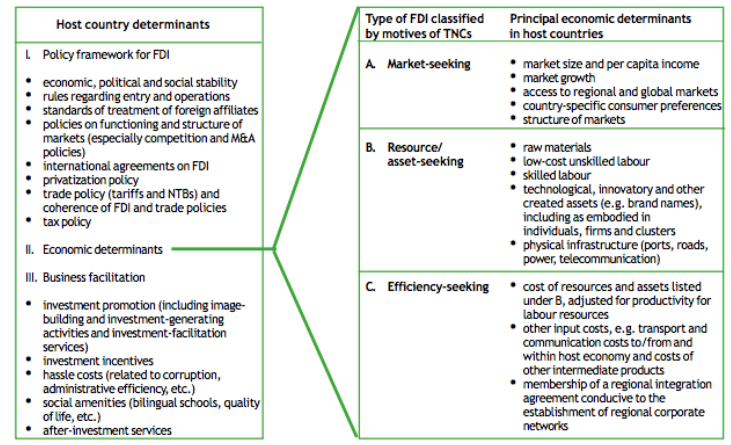

Figure 1. Host Country Determinants of FDI

Source: World Investment Report 1998: Trends and Determinants, Table IV, p.91.

As seen in Figure 1, classification of FDI types of UNCTAD coincides with the model proposed by Dunning. According to UNCTAD, there are three main factors that determine the decision of multinational companies in which country to invest: The policies of host countries, the proactive measures of countries to stimulate and facilitate investments and the characteristics of their economies. Therefore, investors make investment decisions by taking into consideration many different variables depending on location, type of investment and the investment strategy (UNCTAD, 1998).

\section{The Determinants of FDI: Empirical Literature}

Most of the empirical studies for Africa have focused mostly on the natural resource variable, assuming that FDI inflows are resource-seeking. Therefore, most empirical literature has not adequately considered the impact of factors such as the availability of credit, trade openness, telecommunication infrastructure, and macroeconomic stability. There exists an extensive literature on determinants of FDI inflows. In this section of the paper, particularly the studies used similar independent variables in this research included.

Asiedu (2002), using data from 32 developing countries for the period 1970-1999, examined the factors that determine FDI in developing countries, making a distinction between Sub-Saharan African and non SubSaharan African countries. The study revealed a welldeveloped infrastructure and the greater return on capital determines the FDI in non Sub-Saharan African countries, while openness is a good predictor of FDI for both groups of developing countries.

Onyeiwu and Shrestha (2004) described economic growth, openness of the economy, international reserves and the availability of natural resources as determinants of FDI for 29 African countries in the period of 1975-1999. In addition, unlike other studies, they concluded that political rights and infrastructure are not important indicators of FDI inflows to Africa. In the study conducted by Erkisi and Ceyhan (2019) to investigate the relationship between trade liberalization and economic growth in transition economies, it was concluded that economic growth has an impact on FDI in the short-run, however it reduces the FDI in the long-run. In the research carried out by Erkişi (2018) to explore the causal relationship between FDI, trade openness and economic growth in Turkey, economic growth, export, and import were not found to be the granger cause of FDI.

The empirical literature measuring the impact of natural resource endowments on FDI reveals contradictory results. Asiedu (2006), using the panel data analysis showed that natural resource endowments and the big domestic market support FDI inflows to Africa. On the other hand, Basu and Srinivasan (2002) found that some countries in Africa could attract FDI not only due to natural resources, but also through business climate improvement efforts and image development campaigns. Asiedu and Lien (2011) using a dynamic panel model analysis revealed that, the intensity of natural resource exports negatively impacts the FDI inflows.

Research conducted by Wadhwa and Reddy (2011), Udoh and Egwaikhide (2008) and Ahn, Adji and Willet (1998) revealed a negative relationship between inflation and FDI inflows. The reason behind this negative relationship is due to the fact that, inflation is seen as a macroeconomic instability which constitutes a potential risk for the foreign investors. Using time series data for the period 1960-2005, Ang (2008) examined the determinants of FDI inflows to Malaysia. Based on the findings, the author concludes that financial development, infrastructure development and openness encourage FDI inflows. This means that, trade liberalization leads to more FDI inflows in a host country. The findings of this study were also confirmed by Neumayer and De Soysa (2005), who indicated that the FDI inflows of the countries were higher in countries where the trade openness is high.

Demirhan and Masca (2008) analyzed the determinants of FDI inflows in 38 developing countries for the period of 2000-2004 using an econometric model based on cross-sectional analysis. The findings of the study revealed a significant and positive relationship between the growth rate in Gross Domestic Product (GDP) per capita, telephone lines (measured by the number of telephone lines per 1000 people) and trade openness variables as well as FDI inflows. It was also found that, FDI inflows increased as inflation and tax rate decreased in selected developing countries. Sichei and Kinyondo (2012) predicted the determinants of FDI 
inflows by using panel data analysis method for 45 African countries using 1980-2009 annual data. They found agglomeration economies, real GDP growth, domestic and foreign international direct foreign investment policy and the existence of natural resources as the main determinants of FDI inflows to Africa.

Using data from 36 emerging economies for the period of 1990-2000, Liargovas and Skandalis (2011) conducted a panel regression analysis to estimate the impact of trade openness on FDI inflows. Trade openness was found to be an important determinant in the long term for selected Latin America, Asia, Africa, CIS, and Eastern European countries. In addition to trade openness, other factors such as political stability, exchange rate stability and market size (as expressed by GDP) have been found to have a positive impact on FDI inflows. On the other hand, in the study of Seim (2009), the effect of trade openness on FDI shows complex results. While trade openness is an important factor in OECD and Sub-Saharan African countries, the same effect is not seen in oil exporting and non-OECD countries.

Investigating the impact of financial development on FDI by using domestic credit indicators in 10 Middle East and North Africa (MENA) developing countries between 1988-2015, Shah (2016) found that financial development is important for foreign investors' investment decisions. By using data mining technique and data from 78 countries for the period 1980-2009, Korgaonkar (2012) questioned whether financial development has an impact on a country's FDI inflows or outflows. As pointed out by the findings, FDI is not directed towards the financially weak countries and that the development of the financial system of the receiving country is an important prerequisite for the positive effect of FDI on economic growth. On the other hand, using panel data from 38 Sub-Saharan African (SSA) countries, Ezeoha and Cattaneo (2012) investigated the impact of financial development, institutional quality and natural resources on FDI for the period of 1995-2009. However, they could not find a clear evidence of the relationship between the two variables.

Using both transportation and telecommunication indicators, Koyuncu and Ünver (2016) conducted a panel data analysis with univariate and multivariate models in 187 countries for the period of 1990-2014 to explore the effect of infrastructure on FDI inflows. All independent variables caused an increase in FDI inflows. On the other hand, openness to foreign trade, domestic credit to the private sector and urbanization ratio used to control the robustness of the model also had a positive and statistically significant effect on FDI inflows, while no statistically significant effect of population growth and inflation was observed. Tampakoudis et al. (2017) conducted a panel data analysis with the data from 15 middle-income countries for the period of 1980-2013. They emphasized the importance of foreign exchange, GDP and population growth for FDI inflows, while financial development, inflation, infrastructure and fuel exports proved to be insignificant.

\section{Econometric Analysis}

\section{Data Set, Variables and Methodology}

The Data Set consists of 1204 observations of foreign direct investment (FDI), economic growth (GDP), international trade (TRADE), domestic credit (CREDIT), inflation (INF), natural resources (NR) and fixed telephone subscriptions (FTS) series for 28 SubSaharan African countries (Benin, Burkina Faso, Botswana, Central African Republic, Cote d'Ivoire, Cameroon, Congo Dem. Rep., Congo Rep., Gabon, Ghana, Gambia, Kenya, Madagascar, Mali, Mauritania, Mauritius, Malawi, Niger, Nigeria, Rwanda, Sudan, Senegal, Sierra Leone, Eswatini, Seychelles, Chad, Togo, South Africa) between 1975 and 2017. The data set was compiled from World Bank database. In the World Bank's database, the number of Sub-Saharan African countries is 48 . However, only 28 of them are included in this study due to data availability.

Primarily, the model was defined. Before examining the relationships between the series, to choose the proper testing methods, the correlation between the units, the stationarity of the series and the homogeneity of the parameters were examined. After defining the optimal lag-length, cointegration test was performed to define the existence of long-term relationship and PMG Estimator was employed to reveal both the long-term and the short-term relationships of the series of the model.

\section{The Model}

The functional expression of the model is presented in Eq. (1). In the model, FDI is the predicted variable while economic growth (GDP), international trade (TRADE), domestic credit (CREDIT), inflation (INF), natural resources (NR) and fixed telephone subscriptions (FTS) are the predictor variables of the model.

$$
\begin{aligned}
& F D I \\
& =f(G D P, T R A D E, C R E D I T, I N F, N R, F T S)
\end{aligned}
$$

FDI: Foreign direct investment, net inflows (\% of GDP)

GDP: GDP growth (annual \%)

TRADE: Trade (\% of GDP)

CREDIT: Domestic credit to private sector (\% of GDP)

INF: Inflation, GDP deflator (annual \%)

NR: Total natural resources rents (\% of GDP)

FTS: Fixed telephone subscriptions (per 100 people)

Eq.1 the functional model can be expressed in statistical form, as in Eq. (2)

$$
\begin{aligned}
F D I_{i t}=a+ & \beta_{1} G D P_{i t}+\beta_{2} T_{R A D E_{i t}} \\
& +\beta_{3} C R E D I T_{i t}+\beta_{4} I N F_{i t} \\
& +\beta_{5} N R_{i t}+\beta_{6} F T S_{i t}+u_{i t}
\end{aligned}
$$

In Eq. (2), $a$ shows the "constant term", while $\left(\beta_{1} \ldots \beta_{6}\right)$ represents the coefficients that specify the relationship between the predicted variable and the predictor variables; $i(i=1 \ldots . N)$ denotes the countries, and $u_{i t}$ refers to the error term. 
The model can be redefined based on ARDL Model. The re-parameterised ARDL (m, n, n, n) error correction model is expressed as:

$$
\Delta y_{i t}=\theta_{i}\left[y_{i, t-1}-\lambda_{i}^{\prime} X_{i, t}\right]+\sum_{j=1}^{m-1} \xi_{i j} \Delta y_{i, t-j}+\sum_{j=0}^{n-1} \beta_{i j}^{\prime} \Delta X_{i, t-j}+\varphi_{i}+e_{i t}
$$

In Eq.3, $\lambda^{\prime}$ is the vector that symbolises the long-term relationships. The expression of $\left[y_{i, t-1}-\right.$ $\left.\lambda^{\prime}{ }_{i} X_{i, t}\right]$ represents the error correction term. $\xi_{i j}$ and $\beta^{\prime}$ are the short-term dynamic coefficients. The model can be described as:

$$
\Delta F D I_{i t}=\theta_{i}\left[F D I_{i, t-1}-\lambda_{i}^{\prime} X_{i, t}\right]+\sum_{j=1}^{m-1} \xi_{i j} \Delta F D I_{i, t-j}+\sum_{j=0}^{n-1} \beta_{i j}^{\prime} \Delta X_{i, t-j}+\varphi_{i}+e_{i t}
$$

\section{Findings}

Descriptive statistics presented in Table 1 shows the values of observation, mean, standard deviation, minimum and maximum to reveal the characteristics of the series. Once the standard deviation values revised, it can be seen that the series are large enough to explore the variations in the data.

Table 1: Descriptive Statistics

\begin{tabular}{c|ccccc}
\hline \hline Variable & Obs & Mean & Std.Dev. & Min. & Max. \\
\hline \hline FDI & 1204 & 2.441506 & 4.741581 & -28.62426 & 57.83775 \\
\hline GDP & 1204 & 3.599291 & 5.774841 & -50.24807 & 35.62534 \\
\hline TRADE & 1204 & 68.68945 & 34.80827 & 6.320343 & 225.0231 \\
\hline CREDIT & 1204 & 19.01212 & 21.79364 & .4913875 & 160.1248 \\
\hline INF & 1204 & 44.16958 & 787.2167 & -29.69107 & 26765.86 \\
\hline NR & 1204 & 9.983178 & 9.930733 & .00018 & 59.61957 \\
\hline FTS & 1204 & 2.25103 & 5.151343 & .0059913 & 32.65256 \\
\hline \hline
\end{tabular}

It is needed to revise the correlation between the explanatory variables. If the correlation statistic is 0.80 or above, it is an evidence of the linear relationships among the variables and therefore should be dropped because the model does not include both repressors. The outcomes of the correlations between the variables are presented in Table 2.

\begin{tabular}{|c|c|c|c|c|c|c|c|}
\hline Variable & FDI & GDP & TRADE & CREDIT & INF & $\begin{array}{l}\mathrm{NR} \\
\end{array}$ & FTS \\
\hline FDI & 1.0000 & & & & & & \\
\hline GDP & 0.1357 & 1.0000 & & & & & \\
\hline TRADE & 0.3846 & 0.1126 & 1.0000 & & & & \\
\hline CREDIT & -0.0525 & -0.0242 & 0.1418 & 1.0000 & & & \\
\hline INF & -0.0236 & -0.0664 & -0.0380 & -0.0376 & 1.0000 & & \\
\hline NR & 0.1702 & 0.0095 & 0.1691 & -0.2065 & 0.0488 & 1.0000 & \\
\hline FTS & 0.1833 & 0.0166 & 0.4281 & 0.5046 & -0.0198 & -0.2572 & 1.0000 \\
\hline
\end{tabular}

Table 2: Correlation Analysis

The outcomes of correlation analysis in Table 2 show that none of correlation statistics are equal or higher than 0,80 . So, there is no linear relationship between the explanatory variables.

The stationarity of the series or in other words, the integration level of the series is a crucial point to define the proper testing method, which reveals the relationships between the series. One of unit root tests will be employed to explore the integration level of the series. However, to choose the right unit root test method, the cross-sectional dependence between the units should be investigated.

In case of existence of cross-section dependence between the units, "One of the firstgeneration panel unit root tests", otherwise "One of the second-generation panel unit root tests" should be performed.

Pesaran (2004) CD-Test was performed to reveal the cross-section dependence and the outcomes of the test, "Under the null hypothesis of cross-section independence", are reported in Table 3.

Table 3: Pesaran (2004) CD Test Outcomes

\begin{tabular}{l|cccc}
\hline \hline Variable & CD-test & p-value & Corr & Abs(cor) \\
\hline \hline FDI & 29.53 & 0.000 & 0.232 & 0.290 \\
\hline GDP & 6.61 & 0.000 & 0.052 & 0.148 \\
\hline TRADE & 12.21 & 0.000 & 0.096 & 0.310 \\
\hline CREDIT & 34.22 & 0.000 & 0.269 & 0.467 \\
\hline INF & 23.29 & 0.000 & 0.183 & 0.236 \\
\hline NR & 21.16 & 0.000 & 0.166 & 0.347 \\
\hline FTS & 56.93 & 0.000 & 0.447 & 0.559 \\
\hline \hline
\end{tabular}

As seen in Table 4, the p-values of the series are 0.000 and lower than 0.05 . Therefore, the null hypothesis is rejected and it is concluded that, there is cross-section dependence between the units. Therefore, it is needed to employ one of the second-generation unit root test methods in the stationary analysis.

Im, Pesaran and Shin (IPS) is one of the second-generation unit root test that was performed and the null hypothesis " $\mathrm{H}_{0}$ : all panels contain unit roots" is tested against " $\mathrm{H}_{\mathrm{a}}$ : some panels are stationary" and the outcomes are presented in Table 4.

Table 4: IPS Unit Root Test Outcomes

\begin{tabular}{|l|c|c|c|c|}
\hline & \multicolumn{2}{|c|}{$\mathrm{I}(0)$} & \multicolumn{2}{c|}{$\mathrm{I}(1)$} \\
\hline Variable & W-t-bar Stat. & P-value & W-t-bar Stat. & P-value \\
\hline FDI & $-11.8221^{*}$ & 0.0000 & - & - \\
\hline GDP & 10.1302 & 1.0000 & $-18.3484^{*}$ & 0.0000 \\
\hline TRADE & $-3.4724^{*}$ & 0.0003 & - & - \\
\hline CREDIT & 0.7373 & 0.7695 & $-28.5950^{*}$ & 0.0000 \\
\hline INF & $-27.1380^{*}$ & 0.0000 & - & - \\
\hline NR & $-5.8057^{*}$ & 0.0000 & - & - \\
\hline FTS & 0.7635 & 0.7774 & $-16.9336^{*}$ & 0.0000 \\
\hline
\end{tabular}

The outcomes of Table 4 show that FDI, TRADE, INF and NR are stationary at the level because p-values of the statistics are below 0.05, while GDP, CREDIT and FTS are not. However, once the first order differences are taken; GDP, CREDIT and FTS became stationary because p-values of the statistics are below than 0.05 significance levels. As a result, the integration orders of FDI, TRADE, INF and NR are I(0) and the integration orders of GDP, CREDIT and FTS are I(1).

It is needed to define the proper lag-length value. For this purpose, Hansen J Test was employed and the outcomes of the test are presented in Table 5.

Table 5: Optimal Lag-Length Outcomes

\begin{tabular}{|c|llllll|}
\hline lag & CD & J & p-value & MBIC & MAIC & MQIC \\
\hline 1 & .8267265 & 217.9054 & .1354392 & -1120.098 & -174.0946 & -535.0556 \\
2 & .9997853 & 125.6168 & .8986492 & -877.8854 & -168.3832 & -439.1039 \\
3 & .9995617 & 69.15987 & .9879969 & -599.8416 & -126.8401 & -307.3206 \\
4 & .9460737 & 19.86473 & .9999319 & -314.636 & -78.13527 & -168.3755 \\
\hline
\end{tabular}

The lag-length that makes the MBIC, MAIC and MQIC selection criteria minimum is $1 . \mathrm{R}^{2}$ is approx. 
0.83 and significantly high. Therefore, it is concluded that optimal lag-length is 1 .

Pedroni co-integration test was performed "Under a null of no cointegration" to verify the existence of long-term relationships among the series and the outcomes are shown in Table 6.

Table 6: Pedroni Cointegration test Outcomes

\begin{tabular}{|r|c|c|}
\hline & Panel & Group \\
\hline$v$ & 2.883 & $\cdot$ \\
\hline rho $(\rho)$ & -6.105 & -5.744 \\
\hline$t$ & -12.91 & -16.34 \\
\hline$a d f$ & -11.36 & -11.87 \\
\hline
\end{tabular}

The cointegration test outcomes in Table 6 show that, the values of test statistics of $v, \rho, t$ and $A D F$ for both panel and group are above of 1,960 the table value is significant at $5 \%$. Therefore, " $\mathrm{H}_{0}$ : no cointegration" was rejected and it was concluded that, the series are cointegrated. So, there is a long-term relationship between the variables.

As Pedroni Cointegration Test concluded a long-term relationship, Mean Group (MG) Estimator or PMG (Pooled Mean Group) Estimator will be employed to reveal both long-term and the short-term relationships. Hausman Test was performed to determine the most appropriate estimator and the outcomes are reported in Table 7.

\section{Table 7: Hausman Test}

\begin{tabular}{|l|c|c|c|c|}
\hline & \multicolumn{2}{|c|}{ Coefficients-- } & \multicolumn{2}{c|}{} \\
\hline & $\begin{array}{c}\text { (b) } \\
\mathrm{mg}\end{array}$ & $\begin{array}{c}(\mathrm{B}) \\
\mathrm{pmg}\end{array}$ & $\begin{array}{c}\text { (b-B) } \\
\text { Difference }\end{array}$ & $\begin{array}{c}\text { sqrt(diag(V_b-V_B)) } \\
\text { S.E. }\end{array}$ \\
\hline GDP & .0835253 & .0933126 & -.0097873 & .0363265 \\
\hline TRADE & .0654757 & .0250404 & .0404354 & .0317787 \\
\hline CREDIT & -.0134916 & .0113357 & -.0248273 & .0760085 \\
\hline INF & .0198862 & -.0002269 & .0201131 & .0433991 \\
\hline NR & 4.850265 & .0640719 & 4.786193 & 5.206932 \\
\hline FTS & 1.904435 & .0767976 & 1.827637 & 2.166276 \\
\hline
\end{tabular}

Note: " $\mathrm{b}=$ consistent under $\mathrm{H}_{0}$ and $\mathrm{H}_{\mathrm{a}}$; obtained from xtpmg. $\mathrm{B}=$ inconsistent under $\mathrm{H}_{\mathrm{a}}$, efficient under $\mathrm{H}_{0}$; obtained from xtpmg. Test: $\mathrm{H}_{0}$ : difference in coefficients not systematic."

$$
\begin{aligned}
\text { chi-square }(6)= & (b-B)^{\prime}\left[\left(V_{-} \text {b-V_B }\right)^{\wedge}(-1)\right](b-B) \\
= & 3.47 \\
& \text { Prob }>\text { chi-square }=0.7484
\end{aligned}
$$

Table 7 shows the estimations of the coefficients of the variables based on MG and PMG Estimators. The differences between the coefficients (bB), the values of the standard errors, chi-square(6) and probability value of chi-square are reported in Table 7 . The null hypothesis homogeneity through Hausman Test was investigated and because the probability of chisquare is 0.7484 and significantly higher than 0.05 , the null hypothesis is rejected. Therefore, the model supports the PMG Estimator and it is decided to employ PMG Estimator. The outcomes of PMG Estimator are presented in Table 8.

\begin{tabular}{|c|c|c|c|c|c|c|}
\hline \multirow[b]{2}{*}{ dFDI } & \multirow[b]{2}{*}{ Coef. } & \multirow[b]{2}{*}{ Std. Err. } & & \multicolumn{3}{|c|}{$\begin{aligned} \text { Number of obs } & =1174 \\
\text { Number of groups } & 28 \\
= & 40 \\
\text { Obs per group: } \min & 41.9 \\
& =42 \\
\text { avg } & =-2226.481 \\
\max & = \\
\text { Log Likelihood } & =\end{aligned}$} \\
\hline & & & $z$ & $\mathrm{P}>\mathbf{z}$ & $\begin{array}{c}{[95 \%} \\
\text { Inter }\end{array}$ & $\begin{array}{l}\text { Conf. } \\
\text { rval] }\end{array}$ \\
\hline ECT & & & & & & \\
\hline $\begin{array}{l}\text { GDP } \\
\text { TRADE }\end{array}$ & $.0250404^{*}$ & .0078373 & 3.20 & 0.001 & 0096796 & 0404012 \\
\hline CREDIT & $.0113357 *$ & .00421 & 2.69 & 0.007 & .0030841 & .0195872 \\
\hline INF & -.0002269 & .0002087 & -1.09 & & -.000636 & .0001822 \\
\hline $\begin{array}{l}\text { NR } \\
\text { FTS }\end{array}$ & $.0640719 * *$ & .0263 & 2.43 & & .0123857 & .1157581 \\
\hline FTS & $.0767976^{*}$ & .0214576 & 3.58 & 0.000 & .0347416 & .1188537 \\
\hline ECT & $-.5064473^{*}$ & .0596433 & -8.49 & 0.000 & & \\
\hline d.GDP & $-.031779 * *$ & .0126048 & -2.52 & 0.012 & & $\begin{array}{r}.3895446 \\
-.007074\end{array}$ \\
\hline d.TRADE & $.0585378^{*}$ & & & & .0255027 & .0915729 \\
\hline d.CREDIT & -.062922 & .0917204 & -0.69 & 0.493 & 2426907 & .1168466 \\
\hline d.INF & .0010087 & .0045873 & 0.22 & 0.826 & & .0099996 \\
\hline d.NR & 2.483335 & 3.316265 & 0.75 & 0.454 & 4016424 & 8.983094 \\
\hline d.FTS & -.8846854 & .8223834 & -1.08 & 0.282 & & .7271565 \\
\hline cons & -3052921 & .2706389 & -1.13 & 0.259 & $\begin{array}{l}.490527 \\
.8357346\end{array}$ & .2251504 \\
\hline
\end{tabular}

Table 8: PMG Estimator Results

Table 8 covers the coefficient values, standard errors, $\mathrm{z}$ statistics and probabilities belonging to the variables in the model. The upper part of the table shows the long-term relationships. Bottom part of the table shows the short-term relationships. ECT represents the joint effects of the variables.

The long-term results indicated that GDP, TRADE, CREDIT, NR and FTS have a positive impact on FDI because p-values are less than 0.05 the significance level. However, INF does not have an impact on FDI in the long-term. Accordingly;

(a) a $1 \%$ rise in GDP increases FDI by $0.09 \%$

(b) a $1 \%$ rise in TRADE increases FDI by $0.03 \%$

(c) a $1 \%$ rise in CREDIT increases FDI by $0.011 \%$

(d) a $1 \%$ rise in NR increases FDI by $0.064 \%$

(e) a $1 \%$ rise in FTS increases FDI by $0.022 \%$

In the short-term, only GDP and TRADE have an impact on FDI, however, CREDIT, INF, NR and FTS do not have an impact on FDI in the short term. Accordingly;

(a) a $1 \%$ rise in GDP increases FDI by $0.032 \%$

(b) a $1 \%$ rise in TRADE increases FDI by $0.056 \%$

On the other hand, the outcomes of ECT show that, the variables affect each other in the short term and create a joint effect on FDI in the long term. Approximately, $51 \%$ of imbalances in one period will improve in the next period. In other words, it will be balanced in about two years.

\section{Conclusion}

The aim of this study is to investigate the determinants of FDI inflows in Sub-Saharan African countries. In this study, panel data analysis was performed by using annual data from 23 countries for the period of 1975-2017. In order to test the impact of 
market potential, annual GDP growth rate; to test the impact of openness of the countries, trade (export+import) as \% of GDP; to test the impact of financial development in domestic markets, domestic credit to private sector (\% of GDP) variable; to test the impact of macroeconomic stability, inflation (GDP deflator (annual \%) variable, to test the impact of natural resources, which have been considered as the strongest motivation of resource-seeking investment in the region, total natural resources rents (\% of GDP), to test the impact of telecommunication infrastructure, fixed telephone subscriptions (per 100 people) were included as explanatory variables.

Procedures for obtaining the econometric results have been fulfilled. Primarily, the functional, the statistical and the ARDL error correction models were established. The Pesaran (2004) Cross Section Dependence Test was performed to figure out the existence of correlation between the units. IPS Unit Root Test was applied to reveal the stationary level of the series. Hansen J Test was employed to define the proper lag-length value. Pedroni co-integration test verified the existence of long-term relationships among the series and the results of the Hausman test confirmed that, the PMG (Pooled Mean Group) Estimator can be employed to reveal both long and short-term relationships.

Based on the PMG estimator results it can be concluded that GDP growth, trade openness, domestic credits, natural resources and telecommunication infrastructure are the determinants of FDI inflows in SubSaharan countries in the long term. However, in the short term, only the GDP growth and trade openness determines FDI inflows. These findings of the study support the theoretical framework developed by Dunning (1993), who asserts that locations specific factors influence the investor decision. It can also be concluded that, Sub-Sahara African region is not only attracting resource-seeking investments, but it is also marketseeking.

When the results of the study are evaluated as a whole, it can be suggested that in Sub-Saharan Africa, where already substantial efforts are done to improve the business environment, implementation of policies that facilitate import-export transactions, increase financial development, ease the access to natural resources, and extend the telecommunication infrastructure to wider segments of society in Africa is believed to help this region to attract foreign investment.

\section{References}

Ahn, Y. S., Adji, S. S., \& Willet, T. D. (1998). The Effects of Inflation and Exchange Rate Policies on Direct Investment to Developing Countries, International Economic Journal, 12(1), 95104.

Ang, J.B. (2008). Determinant of FDI in Malaysia, Journal of Policy Modelling, 30, 185-189.

Asiedu, E. (2002). On the Determinants of Foreign Direct Investment to Developing Countries: Is Africa Different?, World Development, 30(1), 107- 119.
Asiedu, E. (2006). Foreign Direct Investment in Africa: The Role of Natural Resources, Market Size, Government Policy, Institutions and Political Instability, The World Economy, 29(1), 63-77.

Asiedu, E. \& Lien, D. (2011). Democracy, Foreign Direct Investment and Natural Resources, Journal of International Economics, 84(1), 99111.

Basu, A. \& Srinivasan, K. (2002). Foreign Direct Investment in Africa - Some Case Studies. IMF Working paper WP/02/61, International Monetary Fund: Washington DC.

Buckley, P. J. \& Casson, M. C. (1976). The Future of the Multinational Enterprise, London: The Macmillan Press.

Demirhan, E. \& Masca, M. (2008). Determinants of Foreign Direct Investment Flows to Developing Countries: A Cross-sectional Analysis, Prague Economic Papers, 2008, 4, 356-369.

Denisia, V. (2010). Foreign Direct Investment Theories: An Overview of the Main FDI Theories, Academy of Economic Studies, 2(2), 104-110.

Dunning, J. H. (1977). Trade, Location of Economic Activity and the MNE: A Search for an Eclectic Approach. In B. Ohlin, P. O. Hesselborn, \& P. M. Wijkman, The International Allocation of Economic Activity, London: Macmillan.

Dunning, J. H. (1993). Multinational Enterprises and the Global Economy, Harlow, Essex: Addison Wesley publishing Co.

Erkişi, K. (2018). Foreign Direct Investment, Trade Openness and Economic Growth: A Case of Turkey, The Academic Elegance, 5(10), 189202.

Erkisi, K. \& Ceyhan, T. (2019). Trade Liberalization And Economic Growth: A Panel Data Analysis For Transition Economies In Europe, Journal of Economic, Finance and Accounting, 6(2), 82-94.

Ezeoha, A. E. \& Cattaneo, N. (2012). FDI Flows to SubSaharan Africa: The Impact of Finance, Institutions, and Natural Resource Endowment, Comparative Economic Studies, 54, 597-632.

Hymer, S. H. (1976). The International Operations of National Firms: A Study of Direct Foreign Investment, Cambridge: The MIT Press.

Karluk, R. (2009). Uluslararası Ekonomi: Teori ve Politika, 9. Baskı, İstanbul: Beta Basım. 
Knickerbocker, F. T. (1973). Oligopolistic Reaction and Multinational Enterprise, The International Executive, 15(2), 7-9.

Koyuncu, C. \& Unver, M. (2016). The Impact of Infrastructure on FDI Inflows: A Panel Data Analysis, 2nd International Osmaneli Social Sciences Congress, 12-13-14 October, BilecikTurkey.

Pedersen, K. (2003). The Eclectic Paradigm: A New Deal?, Journal of International Business and Economy, 4(1), 15-27.

Liargovas, P.G. \& Skandalis, K.S. (2011). Foreign Direct Investment and Trade Openness: The Case of Developing Economies, Social Indicators Research, 106 (2), 323-331.

Neumayer, E. and De Soysa, I. (2005). Trade Openness, Foreign Direct Investment and Child Labour, World Development, 33(1), 43-63.

Onyeiwu, S. \& Shrestha, H. (2004). Determinants of Foreign Direct Investment in Africa, Journal of Developing Societies, 20(1-2), 89-106.

Pesaran, M. (2004). General Diagnostic Tests for Corss Section Dependence in Panels. IZA Discussion Paper, 1240.

Seim, L. T. (2009). FDI and Openness: Differences in Response across Countries. Chr. Michelsen Institute, Working Paper.

Shah, M. H. (2016). Financial Development and Foreign Direct Investment: The Case of Middle East and North African (MENA) Developing Nations, MPRA Paper No. 82013.

Sichei, M. M. \& Kinyondo, G. (2012). Determinants of Foreign Direct Investment in Africa: A Panel Data Analysis, Global Journal of Management and Business Research, 12(18), 85-97.

Tampakoudis, I. A., Subeniotis, D. N., Kroustalis , I. G. \& Skouloudakis, M. I. (2017). Determinants of Foreign Direct Investment in Middle-Income Countries: New Middle-Income Trap Evidence, Mediterranean Journal of Social Sciences, 8(1), 58-70.

Udoh, E., \& Egwaikhide, F. O. (2008). Exchange Rate Volatility, Inflation Uncertainty and Foreign Direct Investment in Nigeria, Botswana Journal of Economics, 5(7), 14-31.

Unctad (2019). World Investment Report, Chapter IV Special Economic Zones.

Unctad (1998). World Investment Report Trends and Determinants.
Uneca United Nations Economic Commission for Africa (2016). Investment Policies and Bilateral Investment Treaties in Africa: Implications for Regional Integration, Addis Ababa, Ethiopia.

Vernon, R. (1966). International Investment and International Trade in the Product Cycle, Quarterly Journal of Economics, 80(2), 190195.

Wadhwa, K., \& Reddy, S. (2011). Foreign Direct Investment into Developing Asian Countries: The Role of Market Seeking, Resource Seeking and Efficiency Seeking Factors, International Journal of Business Management, 6(11), 219226. 